\title{
Estetika Bawa dalam Karawitan Gaya Surakarta
}

\author{
Suyoto ${ }^{1}$ \\ Jurusan Karawitan, Fakultas Seni Pertunjukan, Institut Seni Indonesia Surakarta \\ Timbul Haryono dan Sri Hastanto \\ Prodi Pengkajian Seni Pertunjukan dan Seni Rupa, Sekolah Pascasarjana, \\ Universitas Gadjah Mada Yogyakarta
}

\begin{abstract}
ABSTRAK
Penelitian ini difokuskan pada garap vokal terutama estetika båwå untuk mencapai keselarasan båwå atau carem. Penelitian ini menggunakan perpektif musikologis dengan menganalisis berbagai aspek yang berkaitan dengan estetika båwå dalam karawitan meliputi (1) teknik penyuaraan, pernafasan, dinamika, laya, dan kepekaan pathet, (2) jenis-jenis suara yang mendukung capaian keselarasan sajian båwå; dan (3) pelarasan. Hasil penelitian ini menunjukkan bahwa carem merupakan perpaduan dari beberapa unsur musikal membentuk satu kesatuan yang utuh (atut), sehingga menimbulkan keselarasan (runtut). Dengan demikian untuk mencapai båwå pada tataran carem harus memiliki unsur-unsur estetika: suara baik, larasan pleng, menguasai teknik penyuaraan, menguasai teknik pernafasan, mampu mengatur dinamika, mampu mengatur laya, memiliki kepekaan pathet, dan mampu memilih céngkok, sesuai dengan jenis suara. Pelantun båwå yang memenuhi persyaratan ini dapat dipastikan telah mencapai carem.
\end{abstract}

Kata kunci: båwå, råså, Karawitan Jawa, dan estetika karawitan

\begin{abstract}
The Aesthetics of Bawa in Karawitan Style of Surakarta. This study focuses on the vocal creation, especially on the aesthetic of båwa, to achieve the harmony of baiwå, which is called carem. This study is conducted by employing the musicological perspective, by which analyzing the various aspects related to the aesthetics of båwa karawitan style of Surakarta which include the followings: (1) the techniques of voicing, breathing, dynamics, laya, and sensitivity of pathet; (2)types of sounds that support the achievement of Bawa presentation; and (3) sound tunings. The results of this study show that carem is the combination of several musical elements which form a whole unity (atut), so that it will create a sense of harmony (runtut). Therefore, in order to achieve carem, the singer of the baiwa must at least have the aesthetics elements, such as: 1) a good voice and accurate intonation, 2) a good command of vocal techniques, 3) a good command of breathing techniques, 4) the ability to control dynamics, 5) the ability to regulate the laya (tempo), 6) the sensitivity to pathet, and 7) the ability to select céngkok, according to the type of voice. Thus, it can be ascertained that a baiwa singer who meets the above conditions will achieve carem.
\end{abstract}

Keywords: båwå, råså, Javanese Karawitan, and Karawitan aesthetic

\section{Pendahuluan}

Karawitan Jawa yang sampai sekarang masih hidup di tengah-tengah masyarakat, memiliki garap yang cukup kompleks sesuai dengan fungsinya masing-masing. Karawitan yang bersifat mandiri hanya untuk dihayati, di dunia karawitan disebut klenèngan. Selain klenèngan, karawitan dapat digunakan untuk mendukung seni pertunjukan yang lain, yaitu digunakan untuk

\footnotetext{
Alamat korespondensi: : Jurusan Karawitan, ISI Surakarta. Jln. Ki Hadjar Dewantara 19, Kentingan, Surakarta, 57126. E-mail: suyotoskar@gmail.com; HP: 085728417111
} 
mendukung pertunjukan wayang atau karawitan pakeliran, untuk mendukung pertunjukan tari atau karawitan tari (Putra, Prasetya, dan Sunyata, 2014); (Sukistono, 2014: 181). Garap gendinggending wayangan dengan gending klenèngan sedikit mengalami perbedaan, terutama garap vokal. Hanya pada gending-gending klenèngan saja yang biasa menggunakan båwå.

Di dalam klenèngan, ketika mengawali sajian gending biasa disebut buka. Buka dapat dilakukan oleh salah satu instrument (rebab, kendhang, gender, dan bonang) atau menggunakan vokal. Terdapat dua jenis buka menggunakan vokal, yaitu Celuk dan Båwå. Celuk adalah buka gending dengan kalimat lagu pendek yang kadang mengambil dari sebaian teks atau lagu yang digunakan dalam gending (Martopangrawit: 1972: 1). Contoh:

1) Celuk inggah Kinanthi, laras sléndro pathet manyura

$\begin{array}{llllllllllllllllll}6 & 6 & i & i & 2 & 6 & 3 & 2 & 2 & 1\end{array}$

Padhang mbu - lan ke-ken -car -an

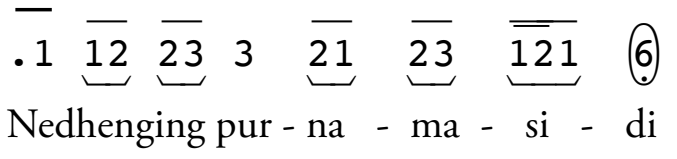

2) Celuk Ketawang Mijil Lurida, laras pelog pathet barang

\begin{tabular}{|c|c|c|c|c|}
\hline 5 & 6 & 7 & 7 & \\
\hline
\end{tabular}

Wastra ngangrang tèbèng - ing pa - ta - ni

Pada contoh 1 celuk menggunakan lagu pendek tidak mengambil bagian dari teks atau lagu dalam gending. Pada contoh 2 celuk teks mengambil bagian awal dari tembang Mijil.

Di dalam karawitan Jawa gaya Surakarta båwå adalah lantunan tembang tunggal atau mandiri dengan penuh kewibawaan untuk memulai sajian gending. Martopangrawit, (1972: 1) menyatakan bahwa båwå adalah sebagai pengganti buka. Jenis tembang yang biasa digunakan untuk båwå adalah: tembang gedhé (sekar ageng), tembang tengahan (sekar tenghanan), dan tembang macapat (sekar macapat). Oleh karena båwå sebagai pengganti buka gending, maka båwå harus tegas, jelas, seperti layaknya $b u k a$ gending, sehingga pengrawit akan tanggap terutama pengendang, akan mudah dalam menerima (nampani) atau istilah dalam karawitan "ngedhahi". Salah satu isyarat bahwa sajian gending diawali dengan båwå, adalah apabila pengrawit menyajikan pathetan terlebih dahulu. Pathetan tersebut sekaligus sebagai isyarat bahwa sajian gending akan diawali dengan båwå. Setelah pathetan selesai kemudian salah satu dari wiraswara menyajikan båwå untuk memulai sajian gending. Ada kalanya båwå menunjuk langsung nama gending tertentu yang akan disajikan setelah båwå. Hal yang demikian ini pengrawit akan lebih siap, karena gending telah disebut di dalam teks båwå.

Pada tahun 50-an, karawitan mengalami perkembangan cukup pesat, terutama garap vokal. Hal ini ditandai dengan munculnya tokoh karawitan Jawa seperti: Ki Martopangrawit, Ki Tjokrowasito, dan Ki Nartosabda (Waridi, 2005:17). Ketiga tokoh ini mengembangkan karya-karyanya dengan melibatkan garap vokal di dalamnya. Ki Nartosabda adalah salah satu tokoh yang lebih dominan mengembangkan garap vokal, baik vokal dalam gending maupun båwå. Suparno (2012), seorang pelantun båwå dalam paguyuban karawitan "Condhong Raos" pimpinan Ki Nartasabda, menuturkan bahwa Nartosabda sangat cerdas dalam menggarap vokal, kadang dengan spontan, tanpa dikonsep terlebih dahulu. Biasanya Nartosabda meminta Suparno mentranskrip garap vokal secara spontan ini. Berawal dari ke tiga tokoh inilah pertunjukan karawitan Jawa terutama garap vokal sampai sekarang masih eksis di masyarakat Jawa, dan vokal menjadi bagian penting dari kehidupan karawitan, termasuk båwå.

Sebelum tahun 1970-an båwå hanya disajikan dalam klenèngan, Santiswara dan Larasmadya. Setelah tahun 1970-an båwå mulai masuk dalam pertunjukan wayang purwa, yakni dalam adegan Limbukan dan gara-gara (Daladi, 2012). Adegan Limbukan berada di wilayah pathet nem, namun gending-gending yang disajikan adalah gendinggending pathet sanga dan manyura, termasuk baiwå disajikan tanpa mempedulikan pathet (Prasetya, 2012). Demikaian halnya adegan gara-gara mengalami hal yang sama. Pada dua dasa warsa terakhir ini, båwå telah merambah ke musik lain yaitu musik campursari, kendatipun båwå yang 
disajikan hanya terbatas pada tembang macapat waosan, dilanjutkan langgam sebagai dhawahnya, karena campursari jarang atau hampir tidak pernah menyajikan gending-gending layaknya dalam karawitan, apalagi gending ageng. Musik campursari hanya terbatas pada gending-gending alit (ladrang, ketawang), atau garap langgam.

Dalam penelitian ini, båwå sengaja dipilih sebagai objek kajian, karena sampai sekarang båwå masih eksis dan memiliki kekuatan di masyarakat secara terbuka dan fleksibel. Hal ini terbukti dalam setiap pertunjukan, baik dalam pertunjukan karawitan maupun wayang, atau dalam seni pertunjukan yang lain, båwå selalu hadir ketika akan disajikan sebuah gending atau lagu. Pada tahun 1990-an, awal munculnya musik campursari mulai diperhitungkan orang, bahkan mampu mencapai boom-nya (Supanggah, 2000: 2). Musik campursari terus berkembang secara menakjubkan, sehingga di beberapa daerah, campursari secara kuantitas sempat menggeser kepopuleran musikmusik yang lain. Musik campursari memang sangat praktis, bahkan dapat menggantikan fungsi gamelan, tidak memakan tempat, mudah diangkut dan ditata, sehingga volume pertunjukan karawitan menjadi berkurang, karena karawitan memerlukan tempat yang luas dan melibatkan banyak orang. Kendatipun demikian, musik campursari masih menyajikan gending -gending Jawa, hampir setiap akan disajikan gending atau lagu diawali dengan båwå. Sekarang ini baik di dalam karawitan maupun seni pertunjukan yang lain båwå selalu hadir dan bisa disajikan oleh siapapun, baik musisi, penyanyi, dan bahkan penikmat. Hal ini menunjukkan bahwa karawitan Jawa di masyarakat mulai terbuka dan sifatnya fleksibel.

Sangat disayangkan, dengan merebaknya båwå di berbagai seni pertunjukan, dengan sifat keterbukaannya, akhir-akhir ini kualitas båwå semakin menurun. Terlepas dari baik atau tidak baik, fakta di lapangan menunjukkan bahwa siapapun berani melantunkan båwå, kadang hanya antem krama, waton wani (asal berani). Akhirakhir ini terdapat fenomena yang cukup menjadi perhatian, yakni sajian båwå diselingi dengan dialog, antara pelantun båwå dengan dhalang, dengan pesindhèn, penyanyi, dan pemandu acara.

\section{Pembahasan}

\section{Estetika Bawa}

Pembicaraan estetika pada artikel ini difokuskan pada nilai keindahan pada båwå dalam karawitan Jawa. Pendekatan yang dilakukan adalah pada estetika obyektif, yakni mencermati unsurunsur yang mendukung kualitas båwå sehingga memiliki nilai estetik. Selain itu nilai keindahan pada båwå tersebut diuraikan melalui pendekatan estetika ekspresif, yakni hubungan antara karya seni dengan perasaan senimannya. Estetika secara mendalam juga banyak diungkapkan oleh para seniman Jawa melalui berbagai medium, seperti gerak, permainan instrumen, bahasa dan sastra, serta suara vokal. Contoh estetika yang diungkapkan lewat bahasa dan sastra dalam karawitan Jawa, dikemas dalam sebuah wangsalan, seperti berikut.

\section{Bagian I. Kusumastra, carem ing rèh palakrama;} Bagian II. Moring gendhing, pinatut lawan irama.

Sebuah karya sastra yang dikemas dalam bentuk wangsalan, seperti tertulis di atas, sering digunakan dalam sindhènan gending-gending tradisi gaya Surakarta. Wangsalan tersebut, dilihat dari bahasa dan keindahan sastranya, sulit untuk dipahami isi yang terkandung di dalam wangsalan tersebut. Memang di Jawa banyak wangsalan yang digunakan dalam sindhènan gending, akan tetapi untuk memahami makna dari wangsalan ini, perlu perhatian khusus dan perlu dianalisis secara mendalam. Wangsalan adalah semacam puisi yang terdiri dari dua bagian, bagian pertama disebut cangkriman atau teka-teki, sedangkan bagian kedua adalah berisi jawaban. Hal senada seperti diungkapkan Mistortoifi (2014: 3) bahwa Kejhungan Madura di dalamnya juga berisi pertanyaan dan jawaban, artinya wangsalan juga berlaku di dalam tembang Madura. Perlu diketahui bahwa wangsalan pada bagian kedua kadang tidak ada hubungannya dengan bagian pertama, akan tetapi di bagian kedua sebagai jawaban yang terselubung dan merupakan inti dari sebuah wangsalan.

Wangsalan bagian pertama, kata kusumastra sebenarnya gabungan dari dua kata, yakni kata kusuma dan astra. Kusuma adalah bahasa kawi yang 
berarti bunga, sendangkan astra juga dari bahasa kawi yang artinya pusaka tradisional orang Jawa, (gaman). Ada dua pusaka tradisional yang menjadi kebanggaan orang Jawa yaitu; keris dan tombak. Keris atau tombak yang baik, menurut orang Jawa adalah yang memiliki pamor yaitu isian atau hiasan yang biasanya berada di bagian samping pusaka tersebut. Dengan demikian kusumastra memiliki arti pamor atau bunga yang ada di dalam pusaka tradisional orang Jawa.

Masih bagian pertama, kata carem juga termasuk bahasa Jawa Kuna yang artinya atut, runtut, lulut. Kata atut, runtut biasa terungkap dalam kehidupan sehari-hari orang Jawa, terutama berkaitan dengan sebuah perkawinan, seperti; atut runtut reruntungan, renggang gula kumepyur pulut. Renggang gula, memiliki pengertian bahwa seandainya ada suatu kerenggangan, diibaratkan renggangnya gula, sedangkan kumepyur pulut, seandainya kepyur atau pudar seperti pudarnya pulut (getah nangka). Ungkapan seperti itu sebenarnya menyangatkan (renggangnya gula, pudarnya getah nangka) betapa eratnya hubungan kedua belah pihak dalam suatu perkawinan. Palakrama adalah basa kramanya rabi, yang artinya kawin atau nikah. Carem ing rèh palakrama, memiliki makna bahwa sebuah perkawinan itu akan diperoleh kenikmatan dan keselarasan hidup.

Wangsalan bagian ke dua, moring gendhing, kata mor ing (lengkapnya adalah amor ing gendhing), oleh karena dibutuhkan 4 suku kata, sehingga menjadi mor ing gendhing. Kalimat mor ing gendhing, merupakan jawaban dari kata kusumastra yang berarti pamor, dengan menyitir suku kata mor dalam kata mor ing gendhing. Masih bagian kedua pinatut lawan irama, kata pinatut merupakan jawaban dari kata carem yang berarti atut, dengan menyitir suku kata tut dalam kata pinatut. Kata carem tersebut merupakan puncak estetika yang tidak dapat diungkapkan dengan kata-kata.

\section{Randai sebagai Orientasi Estetik}

Kata carem seperti diuraikan di atas diangkat dalam sebuah konsep seni, yakni dalam båwå karawitan gaya Surakarta. Carem merupakan ruh dari estetika pertunjukan seni. Konsep carem didudukkan sebagai kunci utama seorang vokalis di dalam melantukan båwå. Keindahan, ekspresi musikal merupakan hal penting yang harus dikuasai oleh seorang pelantun båwå. Ekspresi musikal adalah emosional yang artistik dengan menggunakan nada-nada yang telah diatur (Tyasrinestu, 2014: 164). Mewujudkan båwå yang baik dituntut menguasai keseluruhan sistem dalam berolah vokal, oleh karena itu sajian båwå seolaholah ada ruh di dalamnya, sehingga carem dalam båwå akan dapat dicapai. Carem merupakan hasil lilitan dari beberapa unsur, sehingga menimbulkan sebuah kekuatan yang luar biasa. Beberapa unsur pembentuk keserasian, keselarasan dalam berolah vokal untuk mencapai kualitas maksimal, adalah sebagai berikut. 1) dasar suara baik dengan larasan pleng, 2) menguasai teknik penyuaraan (luk, wiled, gregel), 3) menguasai teknik pernafasan yang baik, 4) mampu mengatur dinamika, 5) mampu mengatur laya, 6) memiliki kepekaan pathet (patheté méncok), 7) mampu memilih céngkok, sesuai dengan jenis suara.

Pelantun båwå yang berkualitas adalah yang mampu manyajikan dengan menguasai berbagai aspek dalam tembang. Dalam dunia vokal, orang menyebutnya sebagai pelantun båwå yang sudah atut, menyatu, dan menjiwai. Pelantun båwå yang demikian ini sudah barang tentu mengalami perjalanan yang cukup panjang, sehingga menguasai berbagai materi garap, memiliki ketrampilan teknik vokal, mampu membangun pola, dan keselarasan, serta memiliki daya batiniyah untuk memancarkan rasa estetik. Petunjuk mengenai kualitas dapat dipahami dari kemampuan pelantun båwå dan pengakuan pendengar atau penikmat terhadap kualitas lantunan båwå. Ketika pelantun båwå telah mencapai carem berarti telah memiliki beberapa unsur, seperti dipaparkan di bawah ini.

\section{Suara}

Tembang adalah seni yang mediumnya suara manusia. Suara manusia adalah produk bunyi ditimbulkan dari getaran pita suara yang terdapat pada tenggorokan manusia, karena hentakan udara yang dimunculkan dari; perut, dada, dan mulut, yang selanjutnya muncul istilah suara mulut, suara dada, dan suara perut. Perlu diketaui bahwa setiap manusia memiliki jangkauan batas-batas 
wilayah nada yang bisa dijangkau oleh manusia, yang kemudian disebut ambitus. Dalam tangga nada diatonis suara pria dewasa babagi dalam 3 golongan. 1) Tenor, 2) Bariton, 3) Bass. Suara wanita dewasa dibagi 3 golongan 1) sopran 2) Mezo sopran, 3) Alto (Basuki dkk, 1996: 27).

Dalam skala internasional (SI), Hertz $(\mathrm{Hz})$ atau cycle per secon (cps) adalah satuan frekuensi. Dalam ilmu fisika memiliki rumus : $f=1 / T$. $T$ adalah periode waktu yang diperlukan oleh benda (dalam hal ini pita suara) untuk melakukan getaran penuh.

Di dalam tangga nada pentatonis (gamelan Jawa), tidak ada penggolongan jenis suara manusia yang diukur secara pasti seperti pada tangga nada diatonis. Hastanto (2009: 88) menyatakan bahwa penggolongan jenis suara dalam gamelan Jawa dikelompokkan menjadi 3 golongan yaitu: suara rendah, sedang, dan tinggi. Demikian halnya suara

\begin{tabular}{|c|c|}
\hline Jenis Suara & Frekuensi \\
\hline Tenor & $130,81 \mathrm{cps} s / \mathrm{d} 440,23 \mathrm{cps}\left(\mathrm{C}-\mathrm{a}^{\prime}\right)$ \\
\hline Bariton & 110 cps s/d 349,23 cps (A-f') \\
\hline Bass & $87,30 \mathrm{cps}$ s/d 293,66 cps (F-d') \\
\hline
\end{tabular}

Tabel 1. Suara pria dewasa

\begin{tabular}{ll}
\hline Jenis Suara & \multicolumn{1}{c}{ Frekuensi } \\
\hline Sopran & 261,63 cps s/d 880 cps (c'-a") \\
Mezo Sopran & $220 \mathrm{cps}$ s/d 698,46 cps (a-f”) \\
Alto & $174,61 \mathrm{cps}$ s/d 587,33cps (f-d") \\
\hline
\end{tabular}

Tabel 2. Suara wanita dewasa manusia, dibuktikan dengan demonstrasi vokalis pria dan vokalis wanita dengan menyuarakan nada yang sama yaitu, wilayah nada 3 (dhadha tengah) sampai nem ageng ( 32216 ). Suara wanita adalah satu gembyang lebih tinggi dari suara pria.

Secara umum dalam dunia vokal untuk menunjuk jenis kualitas suara dapat dikelompokkan menjadi beberapa jenis, yaitu 1) Jenis suara berkaitan dengan volume: gandhang, kung. 2) Jenis suara berkaitan dengan nafas: landhung, cekak. 3) Jenis suara kaitannya dengan bobot: gandhem, anteb, kemèng. 4) Jenis suara kaitannya dengan dasar suara: empuk, atos. 5) Jenis suara kaitannya dengan larasan: arum, langu. 6) Jenis suara berkaitan dengan vibrasi: kempel, serak basah, ngeprèk.

Suharta (2012) mengatakan bahwa suara gandhang dan kung itu hampir sama. Suara gandhang volumenya lebih keras dibanding dengan kung. Pengertian satu nafas adalah penyajian sebuah lagu tanpa memutus di tengah sajian untuk keperluan mengambil nafas. Pelantun båwå yang memiliki intensitas pernafasan pendek, strategi yang digunakan adalah sering memutus lagu båwå untuk keperluan nafas, akan tetapi tetap mempertimbangkan keindahan lagu. Pemenggalan teks sangat dipertimbangkan, karena akan berpengaruh terhadap lagu, serta keberlanjutannya terhadap lagu berikutnya.

Darsono (2012) mengemukakan bahwa kualitas suara anteb baik diperlukan untuk mencapai rasa estetik sajian båwå. Kualitas suara Kemèng tidak tepat direkomendasikan untuk menjadi seorang vokalis. Kualitas suara langu sulit untuk membuat variasi céngkok, wiledan, dan gregel.
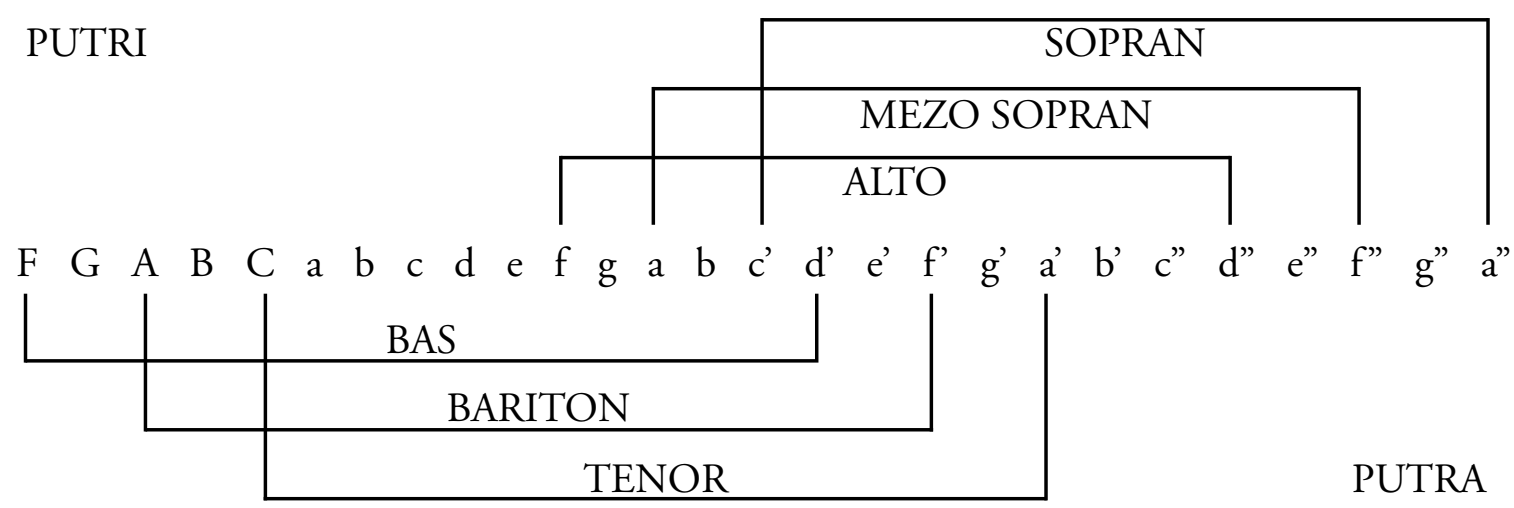

Bagan 1. Ambitus suara manusia dalam tangga nada diatonis 
Kualitas suara Kempel termasuk salah satu kualitas suara yang dibutuhkan dalam penyajian gending-gending yang melibatkan sajian vokal. Suara serak basah kadang dapat menjadi suatu ciri khas seseorang, ketika mampu mengolah secara baik terkait dengan laras, céngkok, variasi wiledan, dan gregel. Tidak jarang orang yang memiliki kualitas suara serak basah, karena kecermatan dalam mengolah, sehingga ketika melantunkan båwå dapat mencapai hasil yang luar biasa (carem). Contoh kongkritnya adalah Sastra Tugiya, seorang vokalis unggulan dalam karawitan Jawa gaya Surakarta. Berkat kepiawaiannya teknik mengolah suara, ketepatan memilih céngkok, maka sajian båwå-nya dapat mencapai carem. Sastra Tugiya sampai sekarang disegani, diidolakan, bahkan ditiru oleh para vokalis generasi berikutnya. Kualitas suara Ngeprèk termasuk kategori suara yang tidak memenuhi syarat untuk keperluan vokal, apalagi untuk menyajikan båwå.

Pada kenyataannya seseorang bisa memiliki beberapa kualitas suara, yakni perpaduan dari dua atau lebih dari jenis suara, yaitu: 1) Gandhang, gandem, kung, landhung, anteb. 2) Empuk, arum, serak basah. 3) Empuk, arum, anteb, kempel. 4) Empuk, arum, renyah.

Suharta (2012) mengatakan bahwa kualitas suara seperti Anom Soeroto sangat cocok untuk dalang, akan tetapi kurang cocok untuk keperluan båwå. Rusman (almarhum) seorang seniman wayang orang dari Surakarta yang karismatik, biasa memerankan tokoh Gathutkaca, Burisrawa atau karakter gagah yang lain. Teknik pelaksanaannya dalam menyajikan tembang agak tekesan kaku (growal-growal). Kualitas suara seperti yang dimiliki Rusman, menurut Darsono (2012) lebih cocok

\begin{tabular}{|c|c|c|c|}
\hline No & Jenis Suara & & Keterangan \\
\hline \multirow[t]{2}{*}{1} & Volume & gandhang & $\begin{array}{l}\text { memiliki intensitas volume keras, bergaung, ambitus luas, } \\
\text { mampu menjangkau pendengar banyak }\end{array}$ \\
\hline & & kung & $\begin{array}{l}\text { memiliki intensitas volume tidak bergitu keras agak meman- } \\
\text { tul, mampu menjangkau pendengar banyak }\end{array}$ \\
\hline \multirow[t]{2}{*}{2} & Nafas & Landhung & $\begin{array}{l}\text { mampu menyuarakan vokal dengan melodi panjang dalam } \\
\text { satu nafas }\end{array}$ \\
\hline & & Cekak & intensitas pernafasannya pendek \\
\hline \multirow[t]{3}{*}{3} & Bobot & gandhem & memiliki kesan mantap, berat, dan menggelegar \\
\hline & & anteb & memiliki kesan mantap, tetapi tidak menggelegar \\
\hline & & kemèng & kualitas suara kecil, kesan ringan \\
\hline \multirow[t]{2}{*}{4} & Dasar suara & empuk & $\begin{array}{l}\text { memberi kesan lembut, halus, tidak terlalu keras terhadap } \\
\text { rasa pendengarnya }\end{array}$ \\
\hline & & atos & $\begin{array}{l}\text { volume keras, tidak mengenakkan, dan memekakkan telinga, } \\
\text { kebalikan dari suara empuk }\end{array}$ \\
\hline \multirow[t]{2}{*}{5} & Larasan & arum & memiliki kesan halus, lembut, dengan larasan pleng \\
\hline & & langu & terdapat penyimpangan laras, sehingga larasan tidak pleng \\
\hline \multirow[t]{2}{*}{6} & Vibrasi & kempel & suara yang vibrasinya bersih, tidak pecah \\
\hline & & serak basah ngeprèk & vibrasinya kurang bersih, kebalikan dari kempel \\
\hline
\end{tabular}

Tabel 3. Jenis Suara Manusia

\begin{tabular}{cll}
\hline No & \multicolumn{1}{c}{ Perpaduan Suara } & \multicolumn{1}{c}{ Seniman } \\
\hline 1 & Gandhang, gandem, kung, landhung, anteb & Anom Soeroto, Rusman \\
2 & Empuk, arum, serak basah & Sastra Tugiya, Karno (RRI) \\
3 & Empuk, arum, anteb, kempel & Suwarto, Slamet Suparno \\
4 & Empuk, arum, renyah & Suparno, Darsono, Sunarno \\
\hline
\end{tabular}


untuk mewakili karakter tokoh tertentu dalam dunia wayang orang, akan tetapi juga kurang cocok untuk keperluan båwå, karena ada kesan kaku.

Perpaduan kualitas suara seperti dimiliki oleh Sastra Tugiya, seorang vokalis karismatik dalam kelompok karawitan Stasiun RRI Surakarta (19551989) menurut Wakidja (2013) diungkapkan berikut.

... pak Sastra ki suarané empuk arum rada ana serakésithik, ya mung napasécekak, ning dhèwèké kuwi pinter ngolah suara, pinter milih céngkok, dadi sak tiba malangangé ki dirungokké sarwa pénak...

(... pak Sastra itu suaranya empuk arum agak serak sedikit, hanya saja napasnya pendek, akan tetapi ia pandai mengolah suara, pandai memilih céngkok, jadi apa yang disajikan itu kedengarannya selalu enak ...)

Kualitas yang dimiliki Sastra Tugiya sangat cocok untuk keperluan dalam klenèngan, seperti båwå, gérong, palaran, kethoprakan, akan tetapi tidak cocok untuk keperluan dalam dunia pedalangan, alasannya kualitas seperti ini kurang gandhang (Suyadi: 2012).

Perpaduan kualitas suara seperti dimiliki oleh Suwarto (almarhum), vokalis pelantun båwå, karawitan Pura Mangkunegaran menurut Suyadi (2013) cocok untuk keperluan dalam klenèngan, akan tetapi ketika melantunkan båwå, gregetnya kurang. Slamet Suparno, vokalis pelantun bawa juga memiliki kualitas suara empuk, arum, anteb. Jenis kualitas suara seperti dimiliki oleh Suparno vokalis karawitan "Condhong Raos" pimpinan Ki Nartosabda, dan karawitan ABDI pimpinan Ki Anom Soroto, cocok untuk keperluan båwå, gérong, dan sindhenan sekar.

Konsep suara yang baik untuk keperluan pertunjukan karawitan ternyata tidak hanya dibangun dari satu kualitas suara saja, melainkan perpaduan dari sejumlah jenis suara. Berbagai kualitas suara yang telah dipahami oleh masyarakat, menunjukkan bahwa suara manusia di dalam masyarakat karawitan Jawa sejak lama telah terdapat konsep baik dan tidak baik. Oleh karena itu, memilih vokalis untuk kepentingan pertunjukan karawitan selalu mempertimbangkan kualitas suara.

Secara estetis kualitas suara baik, oleh masyarakat karawitan Jawa gaya Surakarta dikonsepkan ke dalam istilah gandhang, kung, gandem, empuk, kempel, arum, anteb, landhung. Kualitas suara yang dianggap kurang memenuhi syarat sebagai vokalis dikonsepkan ke dalam istilah atos, kemèng, ngeprèk, cekak, dan langu. Vokalis yang dipandang telah memenuhi persyaratan untuk keperluan pertunjukan karawitan, pada umumnya memiliki perpaduan sejumlah jenis kualitas suara, seperti misalnya: Sastra Tugiya, Suparno, Suwarto, Panut, Slamet Suparno, Darsono, dan Sunarno (almarhum).

\section{Larasan}

Larasan berasal dari kata laras yang dalam dunia karawitan memiliki beberapa arti. Pertama, laras yang berarti nikmat, artinya sesuatu yang dapat dinikmati lewat pendengaran. Kedua, laras yang berarti nada, yaitu suara yang sudah ditentukan frekuensinya, seperti misalnya laras ma, laras $l u$, laras nem dan sebagainya. Ketiga, laras yang berarti tangga nada, yaitu susunan nada-nada yang tertata secara urut tinggi rendahnya dengan jarak nada yang telah ditentukan. Seperti halnya dalam dunia karawitan menggunakan dua laras, yakni laras slendro dan laras pelog. Laras juga memiliki arti register atau cakupan frekuensi nada-nada yang digunakan dalam perangkat musik gamelan (Supanggah, 2002: 86).

Terkait dengan larasan, dikenal istilah pleng dan tidak pleng atau bléro, sasap, numpang, dan sliring. Istilah tersebut terdapat dalam sajian instrumen rebab, yaitu dalam stem (setelan dan pidakan). Pada dasarnya nada yang dimunculkan dari para perebab dan vokalis adalah ekspresi langsung dari pelakunya sendiri. Dengan demikian penyaji terdapat beban mental dan risiko untuk mampu menyesuaikan terhadap nada-nada gamelan. Hasil sajian bisa pleng, bléro, sasap, numpang, dan sliring. Berbeda dengan instrumen lain yang nada-nadanya telah dilaras secara pas, pengrawit yang menyajikan sudah tidak perlu membuat laras lagi, sehingga penyaji tidak ada beban mental dan menanggung risiko untuk 
tidak sesuai dengan larasan gamelan. Kenyataan inilah kemudian muncul konsep pleng, bléro, sasap, numpang, dan sliring. Suara manusia yang sesuai dengan larasan yang telah ditentukan frekuensinya disebut pleng, sedangkan yang tidak sesuai dengan larasan disebut bléro. Suryodiningrat (1983) telah melakukan pengukuran frekuensi terhadap gamelan RRI Solo, hasilnya seperti dalam tabel 5.

\section{Kesenimanan}

Perlu diketahui bahwa kesenimanan seseorang terbentuk dari dua faktor, yakni faktor keturunan dan faktor pendidikan. Faktor pendidikan adalah kesenimanan yang terbentuk melalui proses pendidikan dan latihan secara serius, baik pendidikan formal maupun non formal. Terlepas dari faktor trah atau non-trah, bahwasanya faktor kesenimanan sangat berpengaruh besar terhadap kualitas sajian båwå, karena dari kesenimanannya itu mampu mengolah dan menafsir sesuai dengan kemampuan dan ketrampilan yang dimiliki. Berbeda dengan non seniman, kendatipun memiliki suara yang memadai, akan tetapi tidak memiliki ketrampilan dan kemampuan mengolah vokal sesuai dengan kaidah-kaidah musikal, khususnya dalam bidal vokal, tidak akan mencapai hasil yang maksimal terlebih mencapai carem. Dengan demikian faktor keseniman sangat besar kemungkinannya dalam melantunkan båwå dapat mencapai tingkat carem.

\section{Penjiwaaan}

\section{Laya}

Di dalam karawitan gaya Surakarta laya merupakan salah satu perabot garap untuk menentukan cepat lambatnya sajian gending atau tembang (Supanggah, 2007: 216). Hal yang demikian ini di kalangan karawitan ada yang menyebut kendho kenceng (kendor dan kencang), tamban seseg dalam suatau sajian gending. Martapangrawit (1969: 1) mengatakan bahwa laya adalah cepat dan lambatnya tempo di dalam karawitan. Al Suwardi (2015) mengatakan bahwa laya itu ibarat nafas manusia, ketika orang jalan santai dengan sendirinya keluar masuknya nafas juga santai, longgar, dan pelan. Berbeda dengan orang berlari, sudah barang tentu keluar masuknya nafas menjadi lebih cepat. Hal ini juga bergantung kepada keperluan, disesuaikan nafas yang dimiliki masing-masing individu. Laya dalam sajian gending, bergantung pada irama dalam sajian gending. Laya dalam irama tanggung akan berbeda dengan laya dalam irama dadi, dan berbeda lagi dengan laya dalam irama wiled dan seterusnya. Laya di dalam båwå tidak ubahnya seperti laya dalam sajian gending. Ketika laya diterapkan dalam båwå, juga berhubungan dengan cepat lambatnya sajian båwå, termasuk di dalamnya mengatur angkat dan sèlèh, ke angkatan berikutnya.

Hasil pengamatan dari beberapa pelantun båwå, ditemukan bahwa nafas berpengaruh terhadap laya dalam menyajikan båwå. Sastra Tugiya memiliki nafas cekak, agar laya dalam sajian $b a-$ wa-nya tidak terkesan tergesa-gesa, ia mempunyai teknik tersendiri dalam mengolah céngkok, wiled dan gregel, sehingga laya tetap terjaga dengan baik.

...pak Sastra kuwi napasé cekak, trus suarané cenderung cilik, suara gedhé ora tekan, suara 5 (ma) waé wis ngaya, ning suara cilik tekan, mula yèn gawé céngkok akèh-akèhé angkatané saka ndhuwur, supaya céngkoké kétok (Suharta, 2014).

\begin{tabular}{lll}
\hline No & \multicolumn{1}{c}{ Nama Instrumen } & \multicolumn{1}{c}{ Frekuensi } \\
\hline 1 & Demung pelog & nada $1=294 \mathrm{cycle}$ per secon $(\mathrm{cps})$, nada $7=561 \mathrm{cps}$. \\
2 & Saron barung pelog & nada $1=597 \mathrm{cps}$, nada $7=1061 \mathrm{cps}$. \\
3 & Saron penerus pelog & nada $1=1.197 \mathrm{cps}$, nada tertinggi $=2.151 \mathrm{cps}$. \\
4 & Demung sléndro & nada $6=217 \mathrm{cps}$, nada $!=538 \mathrm{cps}$. \\
5 & Saron barung slendro & nada $6=536 \mathrm{cps}$, nada tertinggi $=1.110 \mathrm{cps}$. \\
6 & Saron penerus slendro & nada $1=1.113 \mathrm{cps}$, nada tertinggi $=2.255 \mathrm{cps}$. \\
7 & Gender barung slendro & nada 6 ageng $=109 \mathrm{cps}$, Nada 3 tinggi $=716 \mathrm{cps}$. \\
\hline
\end{tabular}

Tabel 5. Frekuensi gamelan RRI Surakarta 
[Sastra Tugiya itu nafasnya pendek, suara cenderung kecil, nada 5 rendah saja sudah tidak sampai, maka apabila membuat céngkok kebanyakan mengangkatnya dari nada tinggi, supaya céngkok-nya kelihatan]

Berbeda dengan Suparno yang memiliki nafas landhung, sajian båwå-nya tidak banyak unjal nafas, sehingga laya tidak terkesan tergesa-gesa (kemrungsung). Dengan demikian laya di dalam båwåsangat bergantung pada kepemilikan nafas dari masing-masing pelantun båwå. Laya dalam båwå menjadi penting dan perlu dijiwai oleh pelantun båwå. Laya dalam båwå tidak ubahnya seperti laya dalam gending, sehebat apapun pengrawit menguasai seluruh permainan instrumen, akan tetapi kesalahan laya adalah kesalahan yang sangat fatal, karena dapat menghilangkan keseluruhan rasa gending. Demikian juga dalam båwå, perbedaan céngkok mungkin tidak begitu dipersoalkan, karena di dalam båwå banyak variasi céngkok, dan pelantun båwå memiliki céngkok berbeda. Kesalahan laya di dalam båwå, adalah kesalahan yang sangat fatal, karena dari kesalahan laya itu akan menghilangkan

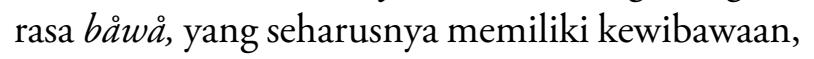
keagungan, dan ketegasan (greget).

\section{Teknik pernafasan}

Teknik pernafasan adalah cara mengatur nafas dalam menyajikan båwå sesuai dengan pedhotan, céngkok, wiledan yang digunakan. Contohnya dapat dilihat pada notasi 1 .

Dalam contoh tersebut sangat jelas perbedaan pedhotan dengan teknik pernafasan. Pada padapala pertama terdapat 4 (empat) pernafasan, yang terdiri dari 3 (tiga) pernafasan panjang ( $\mathrm{N}$ pj) dan 1(satu) pernafasan pendek (N pd). Pada padapala kedua terdapat 5 (lima) pernafasan, yakni 4 (empat) pernafasan panjang dan 1 (satu) pernafasan pendek, dinamakan unjal napas, karena hanya berhenti sejenak untuk mengambil nafas, kemudian angkat lagi seolah-olah tidak berhenti. Padapala ke III dan ke IV lagu sama dengan padapala ke I dan Ke II tanpa ada perubahan.

\section{Garap dan Rasa}

Garap adalah tindakan seniman terkait dengan masalah interpretasi, imajinasi, dan mewujudkan sajian gending dan atau tembang (Supanggah, 2007:3). Dalam karawitan Jawa gaya Surakarta garap merupakan faktor penting dalam menentukan kualitas hasil sajian gending atau tembang. Hal ini tidak bisa lepas dari realitas yang ada, bahwa repertoar båwå dari masa ke masa, baru dalam wujud notasi titilaras dan cakepan, yang sama sekali tidak disertai keterangan tentang cara menyajikannya. Wujud notasi itu belum memiliki makna musikal sebelum disajikan, digarap atau diolah oleh senimannya.

Bawa Sekar Ageng Citrarini, lampah 12, pedhotan 5-7, laras pelog pathet nem.
$6 i \underbrace{\dot{2} . \dot{1} \dot{3}}, \underbrace{i . \dot{2} i \dot{2} \dot{3}} \underbrace{\dot{1} \dot{2} . \dot{1} .6}, 6 \underbrace{65} \underbrace{356} 221216$
I. $\frac{\text { Lir sad - pa }}{N \text { pj }}, \frac{\text { deng }- \text { sun }}{\mathrm{N} \mathrm{pj}}, \frac{\text { tu - mi - ling }}{\mathrm{N} \mathrm{pj}}, \frac{\text { mangu, }}{\mathrm{N} \mathrm{pd}}-$ lat - i;
$332356.5 .46532 .1,66565.32356,22,2123121.6$

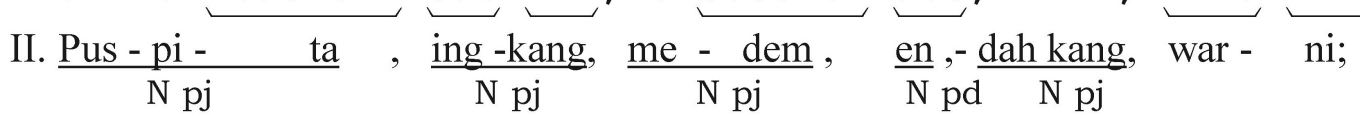

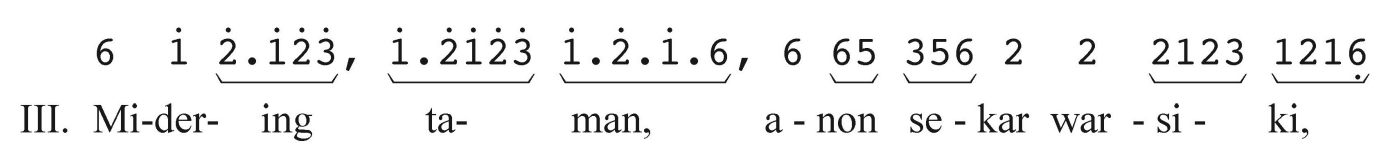
$33 \underbrace{2356.5 .4} \underbrace{653} \underbrace{2.1}, \cdot \underbrace{35} \cdot \overline{\overline{56}} \overline{\overline{53}} 2 \overline{\overline{61}} \overline{\overline{23}} 1 \underbrace{\overline{12}} \overline{\overline{16}}$ (5)
IV Ku-me - nyut ing tyas, ba- ya- ta ja- tu-kra- ma.
Notasi 1. Contoh teknik pernafasan 
Dengan demikian, repertoar båwå yang ada adalah merupakan bahan mentah yang masih harus ditafsir, diwujudkan, dan diterjemahkan lewat bahasa musikal. Dari sini tampak jelas bahwa begitu pentingnya peran pelantun båwå dalam mencapai kualitas hasil sajian båwå-nya. Dengan kata lain pengrawit vokal sangat menentukan dalam mencapai rasa musikal yang disajikan. Realitas yang demikian itu memunculkan sebuah pemahaman bahwa kualitas hasil sajian båwå sangat bergantung pada kemampuan dan pengalaman vokalis dalam mentenerjemahkan notasi dan cakepan ke dalam bahasa musikal.

Dalam kehidupan sehari-hari, rasa orang Jawa, paling tidak dibedakan dalam dua hal yaitu rasa yang besifat lahiriyah dan rasa (feeling) yang bersifat batiniyah. Rasa yang bersifat lahiriyah terdiri dari dua hal. Pertama, rasa pada lidah manusia, seperti rasa manis, asin, asam, gurih, pedas, enak, sedap, sepa, langu, dan sebagainya. Kedua, rasa yang ada dalam jasad manusia, seperti rasa gatal, pegal, linu, nyeri, dan sebagainya. Rasa yang bersifat batiniah adalah rasa yang ada dalam hati, seperti; rasa senang, sedih, haru, galau, takut, dan sebagainya. Rasa dalam konteks karawitan Jawa dapat dimaknai kesan musikal yang ditimbulkan dari hasil sajian gending atau tembang yang dirasakan oleh hati. Benamou (1998:152) menjelaskan rasa dalam makna kualitas, rasa dalam musik dianalogikan dengan persepsi rasa pada lidah, seperti; énak, sedhep, sepa, cemplang, langu, dan sebagainya. Rasa yang demikian itu memiliki efek estetis, yakni

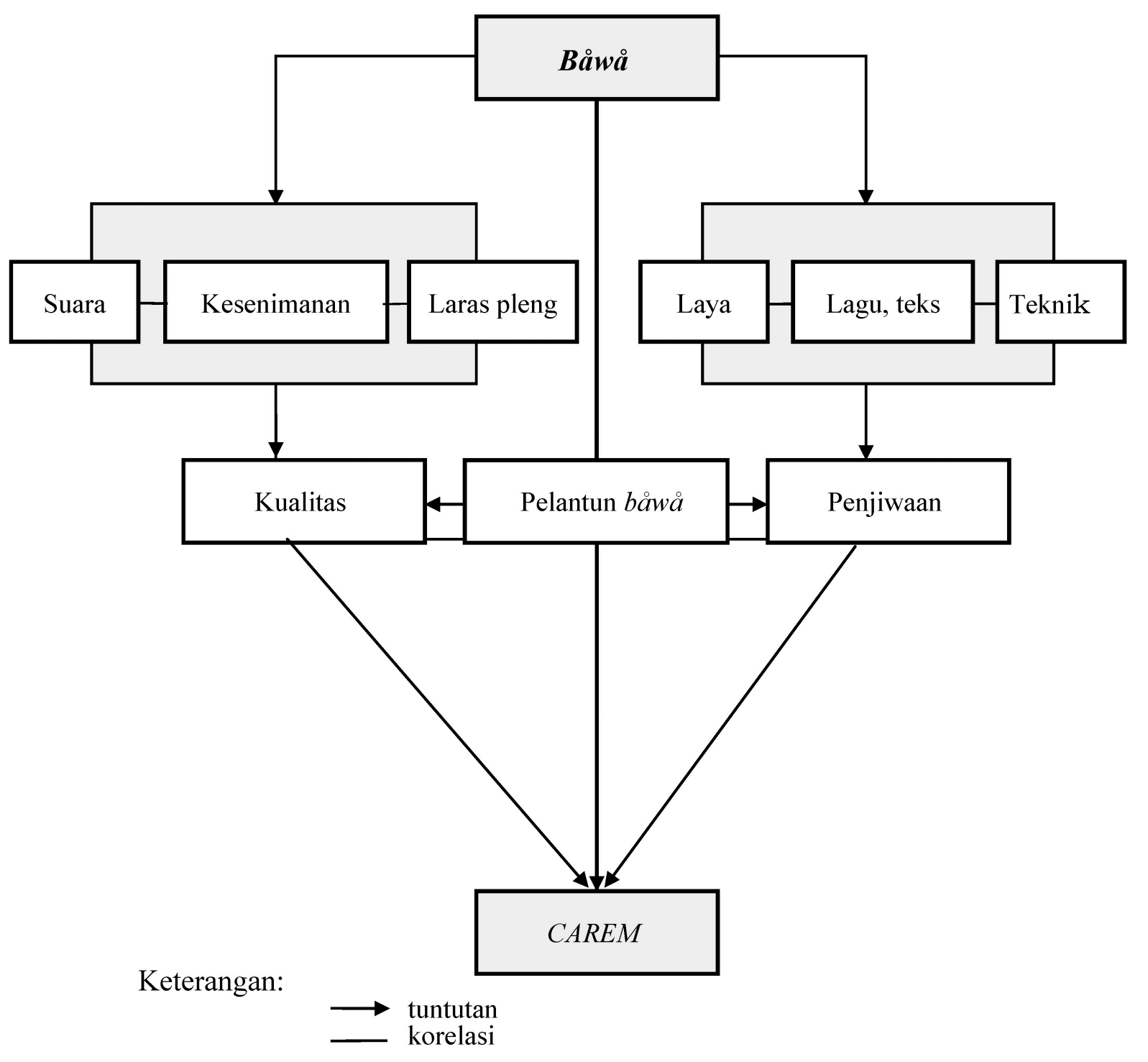

Diagram 2. Konsep mencapai carem 
kesan bunyi yang sampai pada pendengaran. Rasa sebagai sebuah kemampuan, mampu menginterpretasi yang sesuai dengan karakter.

Rasa dalam makna kualitas hubungannya dengan båwå, secara musikal dapat ditafsirkan kualitas hasil sajian båwå. Para pengrawit Jawa dalam menyebut kualitas hasil sajian gending atau tembang, secara individu sering menggunakan padanan kata yang biasa digunakan dalam menilai kualitas rasa makanan. Apabila demikian, jelas bahwa capaian rasa berkaitan erat dengan persoalan garap. Pada umumnya pengrawit Jawa biasa menganalogikan garap gending atau vokal sama halnya dengan cara kerja memasak makanan. Hasil masakan menjadi énak apabila juru masak memiliki wawasan yang luas terhadap berbagai jenis masakan berikut bumbu-bumbu dan takarannya. Artinya, juru masak dapat menghasilkan kualitas rasa makanan dituntut wawasan yang luas, memiliki keterampilan yang baik, dan bertindak secara profesional.

Persoalan garap båwå dapat disejajarkan dengan juru masak, artinya pelantun båwå untuk dapat menghasilkan kualitas rasa sesuai dengan karakternya, dituntut seperti halnya juru ma-

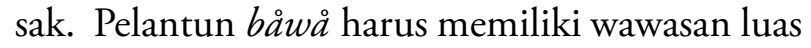
tentang garap vokal berkaitan dengan pemilihan vokabuler céngkok yang sesuai dengan karakter, pengaturan nafas, dan keterampilan memainkan céngkok, wiled dan gregel sesuai dengan céngkok yang dipilih. Pada dasarnya rasa båwå adalah kesan rasa yang ditimbulkan perpaduan dari seluruh persyaratan sebagai vokalis menggarap sesuai dengan karakternya. Apabila demikian, maka rasa båwå sangat ditentukan oleh kemampuan vokalis dalam menggarap båwå yang dituangkan lewat bahasa musikal. Tidak tercapainya aspek-aspek musikalitas semacam itu disebut Ampang, Cemplang, dan Langu.

Ampang yaitu båwå yang tidak memiliki bobot, tidak sesuai dengan sifat dan karakter, kesan rasa båwå ringan tidak berwibawa (ora mbawani), sehingga tidak mampu menyentuh rasa yang mendalam. Hasil yang demikian ini biasanya dijumpai pada pelantun båwå yang tidak memiliki kualitas vokal yang baik, kurang menjiwai, sehingga hasilnya belum mampu menyentuh perasaan pendengarnya.
Cemplang yaitu sajian båwå yang tidak enak didengar, kesan rasa-nya hambar atau tidak sedhap, larasan tidak pleng. Rasa seperti itu juga dapat terjadi dalam gérongan yang semestinya disajikan secara bersama, tetapi tidak mencerminkan kebersamaan. Akibatnya hasil sajian gérongan terasa hambar dan tidak mantap.

Langu adalah sebuah kesan musikal yang terkesan kaku, kasar, dan tidak pleng (rasané ngalor ngidul). Di samping istilah-istilah itu dalam karawitan Jawa gaya Surakarta, juga dijumpai sejumlah istilah yang menunjuk pada kualitas permainan vokal, seperti misalnya; nyindheni, mbawani, dan nggerongi. Hal demikian dapat dipandang memiliki efek estetis terhadap hasil penyajian vokal. Dengan memperhatikan begitu kompleks, berat, dan rumit persyaratan untuk dapat disebut sebagai pelantun båwå yang mbawani, apabila telah memenuhi syarat seperti diuraikan.

Hal yang terjadi pada pelantun båwå juga berlaku bagi perebab, pengendhang dan penggendèr. Perebab disebut telah ngrebabi, manakala mampu menerjemahkan kerangka gending ke dalam melodi-melodi rebaban, mengalir, pleng, serta mampu memberikan ide musikal terhadap permainan instrumen lainnya. Pernyataan untuk menengarai sebagai perebab unggulan manakala hasil permainan rebab-nya bisa mendirikan bulu kuduk para pendengarnya. Penyaji gendèr disebut telah nggendèri, manakala telah mampu menerjemahkan kerangka gending ke dalam permainan gendèr secara mengalir dalam memilih dan menerapkan pola gendèr dan wiletan-nya sesuai dengan esensi karakter gending yang sedang disajikan, serta mampu berinteraksi secara musikal dengan penyaji instrumen garap lainnya. Apabila di dalam permainan instrumen terdapat kualitas permainan yang dianggap baik, di dalam penyajian vokal juga terdapat sejumlah kualitas dan suara yang secara konvensional dipahami oleh masyarakat karawitan Jawa gaya Surakarta.

Berbagai kualitas suara yang dipahami oleh masyarakat karawitan Jawa gaya Surakarta menunjukkan bahwa di dalam masyarakat karawitan Jawa sejak lama yang berkait dengan suara manusia telah terdapat konsep baik dan tidak baik. Oleh karena itu, dalam memilih vokalis 
untuk kepentingan pertunjukan karawitan selalu mempertimbangkan kualitas suara. Kualitas suara yang baik secara estetis oleh masyarakat karawitan Jawa gaya Surakarta dikonsepkan ke dalam istilah gandhang, kung, gandem, empuk, kempel, arum, anteb, landhung. Kualitas suara yang dianggap kurang memenuhi syarat sebagai vokalis (untuk tidak mengatakan jelek) dikonsepkan ke dalam istilah kemèng, ngeprèk, atos, cekak, dan langu.

Konsep suara yang baik untuk keperluan pertunjukan karawitan ternyata tidak hanya dibangun dari satu kualitas suara saja, melainkan merupakan perpaduan dari sejumlah kualitas suara. Masing-masing vokalis yang dipandang telah memenuhi persyaratan untuk keperluan pertunjukan karawitan, pada umumnya memiliki sejumlah kualitas suara yang terpadukan itu. Vokalis seperti Sastra Tugiya, Suparno, Suwarto, Panut, Darsono dan Sunarno adalah contoh kongkritnya.

Di dalam penyajian vokal, dikenal istilah pleng, bléro, sasap, dan sliring. Istilah-istilah ini digunakan untuk menyebut hasil sajian vokal kaitannya dengan laras (nada). Istilah tersebut selain dalam vokal juga terdapat dalam penyajian instrumen rebab, karena pada dasarnya nada-nada yang ditimbulkan dari para vokalis dan pengrebab adalah ekspresi langsung dari pelakunya sendiri. Dengan demikian terdapat beban dan risiko untuk mampu menyesuaikan terhadap nadanada gamelan. Dalam menyesuaikan terhadap nada-nada itu, bisa pleng, bléro, sasap, dan sliring. Berbeda dengan instrumen, bahwa nada-nada pada instrumen selain rebab telah dilaras secara pas, sehingga bagi pengrawit yang menyajikannya sudah tidak ada lagi beban untuk menanggung risiko tidak sesuai dengan nada-nada gamelan. Dari kenyataan inilah kemudian muncul konsep pleng, bléro, sasap, sliring dan sebagainya.

\section{Pleng}

Dalam penelitian ini dalam menentukan nada-nada, sebagai eksperimen digunakan instrumen siter, untuk menstranfer nada atau suara, kemudian diukur menggunakan alat ukur (g strings), untuk menentukan nada itu pleng, blero, sasap, numpang, dan sliring. Di dalam instrumen siter setiap kelompok nada terdiri dari dua dawai yang di stem sama. Setelah diadakan pengukuran nada 6 (nem) memiliki frekuensi 471,40 Hz. Ketika kedua dawai dalam kelompok nada 6 (nem) di stem dengan frekuensi yang sama persis tanpa ada selisihnya, yang demikian ini kemudian disebut pleng. Menurut Hastanto (2012: 20) istilah pleng adalah untuk menandai dua nada yang sama, apabila diukur memiliki frekuensi yang sama persis tanpa ada selisihnya. Istilah pleng di dalam vokal, yaitu menyuarakan nada, sama persis dengan nada gamelan atau nada yang dituju, misalnya nada 6 ageng dalam gender barung slendro memiliki frekuensi $109 \mathrm{cps}$, ketika seorang vokalis menyuarakan nada 6 dengan frekuensi $109 \mathrm{cps}$, kemudian disebut pleng.

\section{Bléro}

Bléro adalah persandingan dua nada yang tidak sama frekuensinya, dengan nada yang dituju atau nada fundamental, bisa lebih tinggi atau lebih rendah dari nada fondamental. Di dalam vokal yang disebut blero adalah menyuarakan nada tidak pas dengan nada yang dituju. Melalui eksperimen dua dawai dalam siter, nada 6 fundamental memiliki frekuensi $471.40 \mathrm{~Hz}$, dawai yang satu di stem 460.40 $\mathrm{Hz}, 10 \mathrm{~Hz}$ lebih rendah dari nada fundamental, kemudian distem dengan frekuensi 482.40, $10 \mathrm{~Hz}$ di atas nada fundamental. Ketika kedua nada itu dibunyikan bersama kedengarannya sangat tidak enak, hal yang demikian ini kemudian disebut bléro. Blero di dalam vokal adalah menyuarakan nada $10 \mathrm{~Hz}$ lebih rendah atau $10 \mathrm{~Hz}$ lebih tinggi dari frekuensi nada fundamental. Kelebihan itu ternyata ada ambang batas toleransi tinggi rendah nada untuk tidak disebut bléro maksimal $10 \mathrm{~Hz}$, apabila lebih tinggi dari $10 \mathrm{~Hz}$, atau $10 \mathrm{~Hz}$ lebih rendah, baru disebut blero (Hastanto: 2012: 10).

\section{Sasap}

Sasap adalah menyuarakan nada-nada baik dalam instrumen rebab maupun vokal berada di bawah larasan gamelan. Suyadi (2013) mengatakan bahwa sasap juga terdapat dalam permainan rebab, yakni pidakan nada-nada selalu berada di bawah larasan atau embat gamelan. Hal yang demikian ini para seniman sering mengatakan "nggawa 
gamelan dhåwê"-membawa gamelan sendiri, karena suara yang dihasilkan tidak cocok dengan gamelan. Dalam eksperimen dawai siter nada 6 fondamental memiliki frekuensi $471.40 \mathrm{~Hz}$, dawai yang satu di stem dengan frekuensi 467.40 $\mathrm{Hz}$, yang demikian ini kemudian disebut sasap. Dengan demikian dapat disimpulkan bahwa sasap adalah menyuarakan nada $5 \mathrm{~Hz}$ lebih rendah dari frekuensi nada fondamental.

\section{Numpang}

Di dalam karawitan istilah numpang biasanya terjadi dalam permainan rebab, yakni dalam steman dua dawai kawat rebab nada 6 (nem) dan nada 2 (ro). Steman numpang adalah nada 6 dan nada 2 frekuensinya lebih tinggi dari nada fondamental, maksimal $5 \mathrm{~Hz}$, kebalikan dari sasap. Demikian halnya di dalam vokal, disebut numpang apabila menyuarakan nada lebih tinggi dari nada fundamental maksimal $5 \mathrm{~Hz}$. Hal ini terjadi ketika lomba karawitan SD, SMP se kabupaten Sragen, tanpa disadari gerongan yang disajikan berada di atas larasan gamelan,yang kemudian disebut numpang. Seandainya tanpa gamelan sebenarnya sajiannya tidak numpang, baru terasa numpang setelah disandingkan dengan larasan gamelan.

\section{Sliring}

Sliring terjadi karena terdapat ketidak stabilan, artinya kadang pleng, suatu saat numpang, dan sasap. Menurut Suharta (2012) sliringadalah menyuarakan nada yang tidak ajeg. Sliring bukan berarti tidak enak, atau tidak baik. Contoh konkritnya adalah Ki Nartosabda dalam melantunkan sulukan dalam pakelirannya termasuk dalam kategori sliring, akan tetapi tidak mengurangi keindahan dalam sulukannya, justru menjadi ciri khas seorang Nartosabda. Kualitas suara seperti yang dimiliki oleh Ki Nartosabda, menurut Suharta tidak cocok untuk melantunkan båwå.

Tiap-tiap hasil sajian vokal memiliki pengaruh yang cukup signifikan terhadap tercapainya estetika yang disajikan. Kategori larasan vokal yang pleng saja yang mampu mencapai tataran rasa estetis yang diinginkan. Dapat dibayangkan begitu rusaknya rasa estetik tembang, apabila vokalnya bléro dan atau sasap, maka sebagus apapun suaranya akan tetapi karena tidak ditopang oleh kaidah-kaidah musikal tidak mungkin dapat dicapai estetik yang prima.

Berdasarkan catatan ditemukan di lapangan dalam masyarakat karawitan Jawa gaya Surakarta terungkap sejumlah istilah yang digunakan untuk menyebut rasa. Istilah ini muncul dari Martopangrawit, Mlayawidada, Soedarsono Wignya Saputra, Sastra Tugiya, Tukinem, Tugini, Suharta, Suroso Daladi, Suparno, Wakijo,Suyadi, Saguh Hadi Carito, dan lainnya. Mereka menyebut sejumlah rasa yang ditimbulkan dari garap vokal adalah sebagai berikut. Rasa mbawani, nyindheni, nggerongi. Istilah ini konon tidak seluruhnya dikenal oleh masyarakat karawitan. Masing-masing hanya mengenal istilah yang akrab dan sering didengar dan diucapkan. Hal ini berkait dengan pandangan masing-masing kelompok terhadap istilah itu, kaitannya dengan pemahaman tentang sikap yang berlaku pada komunitasnya. Hal demikian boleh jadi, karena terdapat kaitan yang erat dengan kebudayaan yang berlaku di keraton. Para pengrawit istana mengenal istilah rasa yang demikian itu dimungkinkan karena di dalam istana semula tidak dikenal keplok, senggak, dan pola permainan kendhang ciblon, imbal bonang, dan dalam sajian klenéngan.

Secara tradisional, estetik musikal gending Jawa gaya Surakarta dapat dilihat dari ketepatan tafsir musikal para pengrawit terhadap gending atau tembang yang disajikan. Ketepatan interpretasi itu dalam bahasa estetika musikal karawitan Jawa diterjemahkan dengan istilah mungguh, enak, lulut, atut.

Mungguh diartikan sebagai nilai kepatutan atau ketepatan garap dalam berolah seni. Dalam karawitan mungguh dapat dimaknai ketepatan dalam memilih cengkok, pola-pola permainan vokal dan atau instrumen. Hal ini suatu indikasi, bahwa untuk menyajikan vokal atau gending dituntut sebuah virtuositas dan kemampuan garap yang tinggi. Enak adalah sajian vokal yang dapat membangkitkan kesan rasa nikmat, selaras (ndudut ati) bagi pendengar atau penikmat seni. Lulut adalah eratnya sebuah lilitan dari berbagai unsur musikal, yang digarap secara profesional. Atut adalah menyatu, artinya menyatunya dari 
beberapa unsur musik, sehingga membentuk suatu kesatuan yang utuh dan menimbulkan keselarasan.

Sebagai pembuktiannya ditampilkan hasil pengamatan terhadap peristiwa pertunjukan karawitan, serta mencermati hasil rekaman suara. Menganalisis rasa harus mendasarkan kepada realitas garapnya saat bawa itu disajikan. Beberapa pertimbangan untuk menganalisis rasa digunakan pendekatan musikologis, yang dapat dijelaskan sebagai berikut. a) Konsep rasa, dalam pengertian estetik tidak cukup hanya mengandalkan sebuah informasi tentang karakter tembang. Realitasnya bahwa beraneka jenis tembang Jawa gaya Surakarta dapat dihayati setelah disajikan. Maka sangat logis bilamana rasa bawa baru dapat ditangkap ketika sudah disentuh oleh seniman dan dihayati setelah bawa itu disajikan. b) Pada dasarnya rasa bawa adalah persoalan kesan yang ditangkap dari hasil sajian yang kemudian menerobos ke dalam batin penghayatnya. Rasa sifatnya adalah imajiner, abstrak, dan non fisik, tidak dapat diraba. Sifat yang imajiner itu berkait erat, bahwa rasa yang sampai pada tingkat carem itu pada awalnya dari hasil imajinasi yang dibangun seniman kemudian diterjemahkan ke dalam bahasa musikal. Maka, carem hanya dapat ditangkap oleh para pendengarnya lewat kepekaan merasakan terhadap sesuatu yang menyentuh jiwa. Jadi, rasa hanya dapat ditangkap lewat kecerdasan emosional para penghayatnya, dan bukan lewat kecerdasan intelektual. c) Setiap generasi memiliki cara yang berbeda-beda dalam mengekspresikan diri dan menafsir serta mengaktualisasikan bawa. Dalam hal demikian sangat mungkin terdapat pergeseran cara pandang dalam memakna rasa dari sudut pandang estetik.

Contoh penyajian bawa, penyajian sindhénan, dan jenis vokal lainnya yang oleh generasi tertentu dianggap baik belum tentu dianggap baik oleh generasi berikutnya. Misalnya, teknik sèlèh penyajian lagu sindhèn pada zaman dahulu yang dianggap baik adalah yang tepat sèlèh lagu kenong dan sèlèh lagu gong atau hanya diberi toleransi melampaui setengah ketukan dari dua sèlèh itu. Pada masa-masa berikutnya penyajian sindhénan yang demikian itu justru dipandang kurang enak karena terkesan kaku. Hal ini terungkap ketika wawancara denganTukinem (pesinden sepuh karismatik), Tugini (pesinden senior R.R.I Surakarta).

Hal penting yang perlu menjadi catatan, bahwa sindhénan Ibu Tukinem oleh masyarakat karawitan Jawa gaya Surakarta dipahami sebagai sindhénan yang karismatis dan banyak dicontoh oleh pesindhèn pada generasi berikutnya. Begitu pula pelantun bawa Sastra Tugiya yang diakui sebagai seorang pelantun bawa terbaik dalam dunia karawitan Jawa gaya Surakarta dan banyak diidolakan oleh para vokalis pria, menuturkan bahwa pelantun bawa yang baik adalah yang mampu menyajikan bawa dengan beraneka ragam variasi-variasi. Variasi dibuat justru dalam rangka untuk memberikan bobot lagu bawa yang disajikan. Memasukkan sedikit variasi lagu sindhénan ke dalam sajian bawa, bukan berarti mengakibatkan sajian båwå menjadi terasa nyindheni dan mengurangi rasa bawa, tetapi justru sebaliknya menjadikan bawa yang disajikan semakin enak.

Ketika seseorang melantunkan båwå dengan kualitas baik, biasanya kewibawaanya sampai mempengaruhi lingkungan sekitarnya: semua orang diam dan mendengarkan. Bawa seharusnya kelihatan jantan, berwibawa, karena pada awalnya pelantun bawa adalah laki-laki, akan tetapi karena perkembangan jaman, sekarang båwå juga disajikan oleh seorang wanita. Ketika seorang wanita melantunkan båwå, sulit untuk mengajarkan båwå tersebut kepada mereka, kecuali yang dapat dilakukan mungkin hanya memberikan céngkok (pola-pola melodis) suara yang maskulin, dan berharap, mereka dapat melakukannya dengan baik. Hanya sebagian kecil wanita yang memiliki kemampuan melantunkan båwå, tampak berwibawa. Akan lebih jarang lagi di antara mereka yang dapat menyajikan sindhèn, diminta untuk menyanyikan bawa menyerupai bawa-nya seorang pria mungkin tidak ada, dan akan banyak permasalahan yang akan ditemui. Mungkin terdapat beberapa bagian yang justru akan menyerupai lagu sindhenan. Tanpa mereka sadari, mereka mengalami dua atau tiga ornamen sindhènan yang berbaur dalam båwå mereka.

Gaya båwå harus dibedakan dengan gaya sindhèn bahkan dengan jenis-jenis vokal lainnya. 
Akan tetapi yang jauh lebih penting dan perlu dicermati, serta harus hati-hati adalah untuk tidak mengatakan, bahwa bawa harus 100\% bersih dari jenis-jenis vokal lainnya. Berdasarkan sejumlah pengamatan tidak dijumpai seorang pun penyaji bawa yang tidak terdapat pengaruh dari jenis vokal yang lain. Penyaji båwå adalah seorang seniman yang memiliki imajinasi, kreativitas, serta suara yang baik, memiliki kebebasan untuk mengekspresikan lagu bawa sesuai dengan keyakinannya. Sastra Tugiya sebagai seorang vokalis karismatik yang kaya pengalaman dalam pertunjukkan karawitan, pasti berbeda dengan Suharta yang guru tembang dalam memaknai båwå. Biasanya pelaku bawa sangat memperhatikan berbagai aspek dalam melantunkan båwå termasuk dalam membuat variasi- variasi agar sajiannya lebih menarik. Akan tetapi bagi seorang yang berlatar guru atau pelatih båwå lebih banyak mempersoalkan kaidah-kaidah yang kadang juga kurang jelas asal-muasal kaidahkaidah itu. Saling meminjam variasi dalam tembang Jawa adalah hal yang biasa, kendatipun masingmasing dipahami memiliki konsep penyajian yang berbeda-beda. Oleh karenanya dalam memaknai bawa harus disikapi secara lebih longgar. Dalam penyajian bawa yang jauh lebih penting adalah mengupayakan bagaimana sajian bawa dapat memancarkan estetika. Sesuatu dapat dirasakan ketika sesuatu itu telah menyentuh indera sensa manusia

\section{Penutup}

Dalam karawitan gaya Surakarta terdapat dua unsur penting, yaitu instrument dan vokal. Vokal dimaksud adalah: sindhenan, bawa, gerong, senggakan, dan alok, yang kehadirannya untuk menambah indahnya sajian karawitan. Tidak sembarang orang bisa menyajikan vokal, terutama vokal tunggal (sindhenan dan bawa). Pelantun bawa, paling tidak memiliki kualitas suara yang baik, dan memiliki kemampuan berolah vokal yang memadai. Di dalam karawitan terdapat sejumlah kualitas dan jenis suara sebagai estetika vokal terutama bawa yang secara konvensional dipahami oleh masyarakat karawitan. Istilah dimaksud adalah; 1) jenis suara berkaitan dengan volume: gandhang, kung. 2) berkaitan dengan pernafasan: landhung, cekak. 3) kaitannya dengan bobot: gandhem, anteb, kemèng, 4) berkaitan dengan kelenturan: empuk, atos. 5) kaitannya dengan larasan: arum, langu. 6) kaitannya dengan vibrasi: kempel, ngeprèk, serak. 7) kaitannya dengan ambitus: tekan, ngaya. Kualitas suara yang baik, secara estetis oleh masyarakat karawitan dikonsepkan ke dalam istilah: gandhang, kung, gandem, empuk, kempel, arum, anteb, landhung. Kualitas suara yang dianggap kurang memenuhi syarat sebagai vokalis dikonsepkan ke dalam istilah: kemèng, ngeprèk, atos, cekak, dan langu.

Segala jenis kesenian akan mencapai pada tataran rasa yang paling tinggi atau mencapai keselarasan yang luar biasa yang menurut orang Jawa disebut "carem". Melantunkan bawa untuk dapat mencapai carem paling tidak: memiliki dasar suara baik larasan pleng, menguasai teknik penyuaraan (céngkok, luk, wiled, gregel), menguasai teknik pernafasan, mampu mengatur dinamika, mampu mengatur laya, memiliki kepekaan pathet, dan mampu memilih céngkok sesuai dengan jenis suara.

\section{Kepustakaan}

Benamou, March. 1998. "Rasa in Javanese Musical Aesthethics". [Disertasi]. Michigan: Department of Musicology, The University of Michigan.

Prasetya, Hanggar Budi. 2012. "Pathet: Ruang Bunyi dalam Karawitan Gaya Yogyakarta" dalam PANGGUNG JURNAL SENI DAN $B U D A Y A$, Vol 22, No. 1- Januari 2012: 6782.

Hastanto, Sri. 2009. Konsep Pathet Dalam Karawitan Jawa. Surakarta: Program Pasca Sarjana.

2012. Ngeng \& Reng Persandingan Sistem Pelarasan Gamelan Ageng Jawa dan Gamelan Bali. Surakarta: STSI Press.

Kutha Ratna, Nyoman. 2007. Estetika Sastra dan Budaya. Yogyakarta: Pustaka Pelajar.

Martopangrawit. 1975. Gendhing-Gendhing Santiswara Jilid I dan II. Surakarta: ASKI Surakarta. 
1967. Tetembangan, Surakarta: A.S.K.I. Surakarta.

Mistortoify, Zulkarnain. 2014. "Pola Kelléghan dan Teknik Vokal Kejhungan Representasi Ekspresi Budaya Madura dan Pengalaman Estetiknya" dalam RESITAL: JURNAL SENI PERTUNJUKAN, Vol 15, No. 1- Juni 2014: 3.

Soedarsono, RM. 2002. Seni Pertunjukan Indonesia di Era Globalisasi. Yogyakarta: Gadjah Mada University Press.

Sugiyarto, A., et al. 1997. Gendhing-Gendhing Karya Ki Nartosabda Jilid 4, Semarang: Departemen Pendidikan dan Kebudayaan.

Sukistono, Dewanto. 2014. "Pengaruh Karawitan Terhadap Totalitas Ekspresi Dalang dalam Pertunjukan Golek Menak Yogyakarta" dalam RESITAL: JURNAL SENI PERTUNJUKAN, Vol 15, No. 2- Desember 2014: 179-189.

Sumarsam. 2002. Hayatan Gamelan Kedalaman Lagu, Teori, dan Perspektif Surakarta: STSI Press,.

2003. Gamelan: Interaksi

Budaya dan Perkembangan Musikal di Jawa. Yogyakarta: Pustaka Pelajar.

Supanggah, Rahayu. 2002. Bothekan Karawitan

I. Jakarta: Masyarakat Sèni Pertunjukan Indonesia. 2007. Bothekan Karawitan II. Jakarta: Masyarakat Sèni Pertunjukan Indonesia.

Suparno, T.S. 1990. "Pemunculan dan Pengembangan Karawitan Mangkunegara: Kronologi Peristiwa Karawitan di Mangkunegaran 1757-1881” [Tesis] Universitas Gadjah Mada, Yogyakarta.

Suyoto. 1996. "Bawa Gawan Kaitannya dengan gendhing" Suatu Kajian Tekstual. [Laporan Penelitian] STSI Surakarta. 1992. "Sindhenan Gendhing Sekar Versi Sastro Tugiyo" [Laporan Penelitian] STSI Surakarta.

Tyasrinestu, Fortunata. 2014. "Lirik Musikal pada Lagu Anak Berbahasa Indonesia” dalam
RESITAL: JURNAL SENI PERTUNJUKAN, Vol 15, No. 2- Desember 2014: 163-168.

Waridi. 2001. R.L. Martopangrawit Empu Karawitan Gaya Surakarta. Yogyakarta: Penerbit Mahavira.

2005. "Tiga Pilar Kehidupan

Karawitan Jawa Surakarta Masa Pasca Kemerdekaan Periode 1950-1070 an. [Disertasi] Universitas Gadjah Mada, Yogyakarta.

Waluyo. 1992. "Bawa Gawan gendhing Versi Sastro Tugiyo" [Laporan Penelitian] STSI Surakarta.

\section{Informan}

Darsono (56 tahun). Seniman karawitan dan vokalis. Tinggal di Kampung Tegalsari, Surakarta.

Daladi, Suroso (72 tahun). Seniman karawitan ahli dibidang vokal. Tinggal di Surakarta.

Suharta (68 tahun). Seniman karawitan gaya Surakarta ahli dibidang vokal. Tinggal di Perum Mojosongo, Surakarta.

Suparno (66 tahun). Seniman karawitan gaya Surakarta ahli dibidang vokal dan mantan vokalis paguyuban karawitan "Condhong Raos" Pimpinan Ki Narto Sabdo. Tinggal di Kampung Pasekan, Mudal, Boyolali.

Suyatmi (59 tahun ). Swarawati paguyuban karawitan "Mayangkara" Pimpinan Ki Purbo Asmoro dan mantan swarawati karawitan "Condhong Raos" Pimpinan Ki Narto Sabdo. Tinggal di Kampung Mudal. Boyolali.

Suyadi (68 tahun). Seniman karawitan dan mantan pimpinan karawitan RRI Surakarta. Tinggal di Perum Mojosongo, Surakarta.

Tukinem (81 tahun) meninggal tahun 2015. Swarawati gaya Surakarta dan mantan pegawai RRI Surakarta unit karawitan. Tinggal di Kampung Serengan, Surakarta.

Wakidja (69 tahun). Pengendhang dan mantan pimpinan karawitan RRI Surakarta. Tinggal di Surakarta. 